Int. J. Morphol.,

35(1):167-171, 2017

\title{
Quantitative Study on Human Cerebellar Cortex from Anatomy Cadaver Preparations
}

\author{
Estudio Cuantitativo de la Corteza del Cerebelo Humano \\ a Partir de la Anatomía de Preparaciones Cadavéricas
}

Kalanjati, V. P.; Dewi, A. K. \& Santoso, M. W. A.

KALANJATI, V. P.; DEWI, A. K. \& SANTOSO, M. W. A. Quantitative study on human cerebellar cortex from anatomy cadaver preparations. Int. J. Morphol., 35(1):167-171, 2017.

SUMMARY: Human cerebellum is important for motor coordination; muscle tones and maintaing the equilibrium of the body. In our region, limited data is available on the normal morphology of human cerebellum, whilst fresh biopsy is quite difficult to obtain. Here adult male cerebellum from cadaver anatomy preparations embalmed with $37 \%$ formalin fixative solution for over a year are studied ( $\mathrm{n}=3$ ). After removal, right cerebellum hemisphere was sliced into cubicle then temporary soaked into 50-60\% of alcohol before being paraffinated. Two parasagittal adjacent slices from each sample were deparaffinated $(5 \mu \mathrm{m})$ and then stained with hematoxyllin-eosin (HE). Slides were observed under light microscope (Olympus, Japan). Pictures were analysed from 6 field numbers of each, with Optilab and Image Raster 3 software (Indonesia). The density of the Purkinje cells (Neuron purkinjense), the number and density of the Purkinje cells and the thickness of the molecular layer are measured. Data were analysed with the level of significance of $\mathrm{p}<0.05$ (ANOVA, Microsoft Excel 2007). The distance between 2 Purkinje cells is ranged between $82.6-346.6 \mu \mathrm{m}$, although no significant differences found ( $\mathrm{p}=0.1$ ). There are no significant differences in the number and in the density of the Purkinje cells amongst samples ( $\mathrm{p}=0.72$ and 0.34 , respectively); might be due to the similar age, sex and race of these cadavers. However, there is a significant difference in the thickness of the molecular layer $(\mathrm{p}=0.015)$. Variations amongst individual cerebelli are observed, with a significant different thickness in the molecular layer. The cellular composition of each cerebellum is unique, arguably correlated to the individual cerebellum activity when alive.

KEY WORDS: Metencephalon; Cerebelar cortex; Measurement; Structure.

\section{INTRODUCTION}

Cerebellum is a part of central nervous system. It is a structure of the metencephalon, and together with pons and the fourth ventricle, constructed a human rhombencephalon (Ellis, 2006; Fitzgerald et al., 2012). According to its development, cerebellum can be divided in general into archicerebellum, paleocerebellum and neocerebellum. The archicerebellum consisted of the flocculonodule lobules and the fastigial nuclei. The paleocerebellum includes the globose and emboliform nuclei with the vermis and the paravermis area. The neocerebellum is the dentate nuclei with the cerebellar hemispheres (Waxman, 2010; Crossman \& Neary, 2015).

The histology of cerebellum is generally defined as 3 layers, from superficial to the deepest part are: molecular layer, Purkinje cells layer/piriform layer (Stratum purkinjense) and the granular cells layer which reside in the cortex; whilst the rest is the cerebellar medulla with white matters as the predominant member (Watson et al., 2010). The Purkinje cells (Neuron purkinjense) seems to play vital roles in the cerebellum connectivity to other brain area, especially via the dentate nuclei and cerebellar cortices, to correlate to the cerebral cortices, red nuclei of the mesencephalon, the ventral lateral nuclei of thalami and pons (Watson et al., 2010; Fitzgerald et al.).

Fresh biopsy sample is better prepared to study human's cerebellum. However here, this becomes a problem due to the limited sources. Thus, we study the possibility to analyse the morphology of human cerebellum from the anatomy cadavers. These cadavers have been fixated for over a year in a high formalin fixative solution, which contains a much higher percentage of formaldehyde than the usual histology fixative solutions (>10 \%) (Kalanjati et al., 2012). To our best knowledge, human cerebellum characteristic has not studied extensively in our region. The current study aims to analyse the cellular population of the Purkinje cells and the thickness of the molecular layer of human cerebellar cortex from anatomy cadaver preparations. 


\section{MATERIAL AND METHOD}

The current study has an approval from The Ethic Committee of Faculty of Medicine, Airlangga University, Surabaya, Indonesia (Approval No. 42/ KEPK/ FKUNAIR/ 2016). Adult male cadavers were obtained from The Department of Anatomy and Histology, Faculty of Medicine, Airlangga University, Surabaya, Indonesia $(n=3)$. The age of these cadavers is approximately 60-70 years old; all were homeless who passed away due to natural causes in the general county hospitals in East Java, with no blatant brain's injury or lesion. They were all of native people of Indonesia.

All cadavers were embalmed by injecting a high containing formalin fixative solution $(37 \%)$ via the femoral artery. Details were explained elsewhere (Kalanjati et al.). After removing the braincase, the whole encephalon from each cadaver was removed from the base of cranium. The cerebellum from each encephalon was separated and sliced parasagitally after blocked with paraffin. Two adjacent sections $(5 \mu \mathrm{m})$ from each sample were sliced and then deparaffinated prior to staining process with HE (IHC World 2011a,b, 2015). Each slide was then observed under the light microscope (Olympus, Japan), with 40;100; 400 xs of magnification. Figures from each slide were taken with digital camera (Nikon, Japan) and then analysed with Optilab and Image Raster 3 software (Indonesia). Slides with artefacts were excluded (Chatterjee, 2014). We analysed: (1) the total numbers of the Purkinje cells, (2) the distance between 2 Purkinje cell's nuclei, (3) the density of the Purkinje cells, which is measured from the total distance of all Purkinje cells divided by the number of the Purkinje cells of each field number, (4) the thickness of molecular layer, which is measured from the average distance of 3 random Purkinje cell's nuclei to the diametric of its most superficial molecular layer (Fig. 1). All readings of sections were done at least twice independently, which was observed from 6 field numbers of each cerebellum. Analysis of variance (ANOVA) was used to analyse whether there are significant differences in each variable amongst these 3 cadavers (Microsoft Excel, 2007). Level of significance is reached when $\mathrm{p}<0.05$.

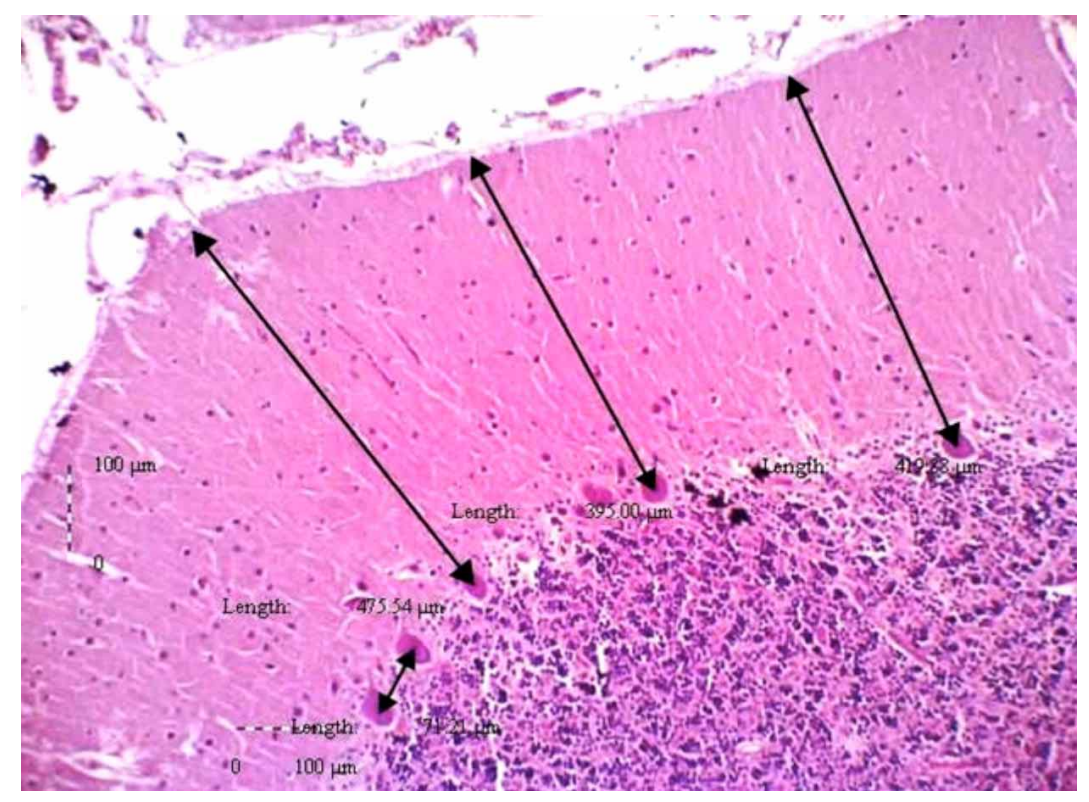

Fig. 1. A slide of adult human cerebellum (magnification of $100 \mathrm{xs)}$ ). From each field number we analysed the number of Purkinje cells, (a) the total distance between the nuclei of all Purkinje cells and (b) the thickness of the molecular layer from each Purkinje cell's nucleus and the uttermost part of the diametric molecular layer.

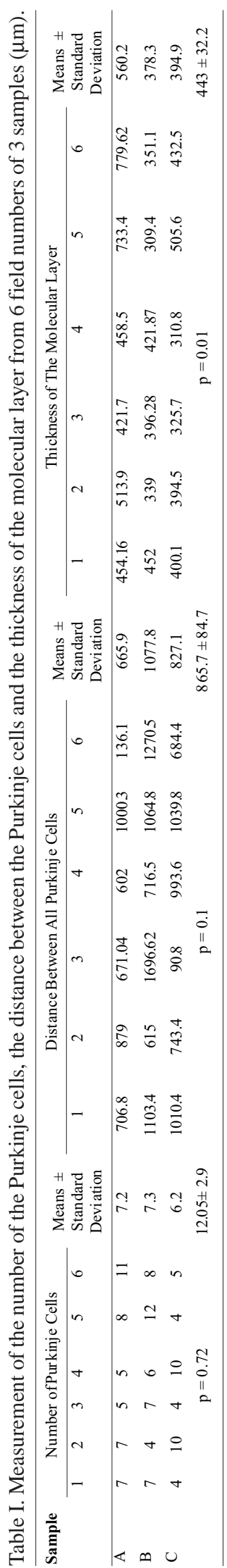



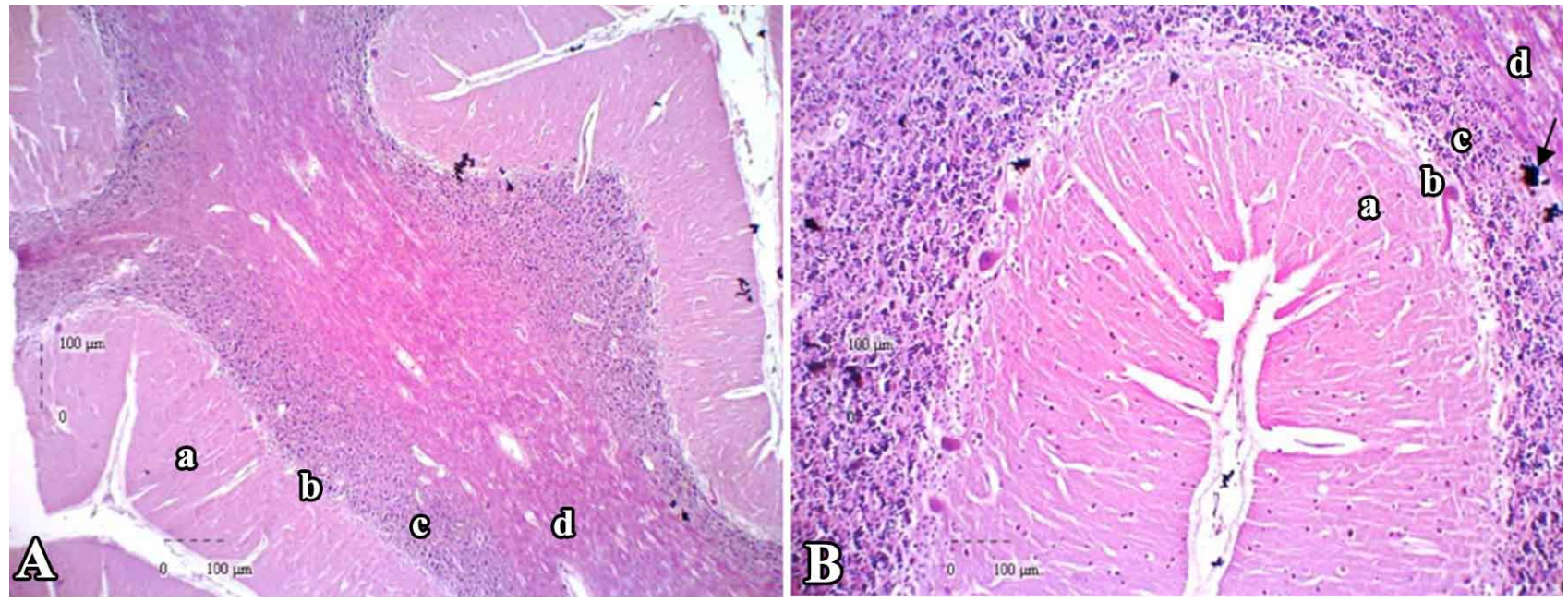

Fig. 2a. Adult human cerebellum from anatomy cadaver preparation (magnification of $40 \mathrm{xs}$ ). The folia of cerebellar cortex can be seen clearly at the superficial part of (d) the white matter, together with the laminations of (a) the molecular layer, (b) the pirifom layer and (c) the granular layer.

Fig. 2b. Adult human cerebellum from anatomy cadaver preparation (magnification of $100 \mathrm{xs}$ ). The cerebellar cortex is demonstrated clearly with the laminations of (a) the molecular layer, (b) the pirifom layer and (c) the granular layer; whilst (d) is the white matter of cerebellar arbor vitae. Here, some blemishes from HE staining is seen, although the overall slide is still acceptable (arrow).

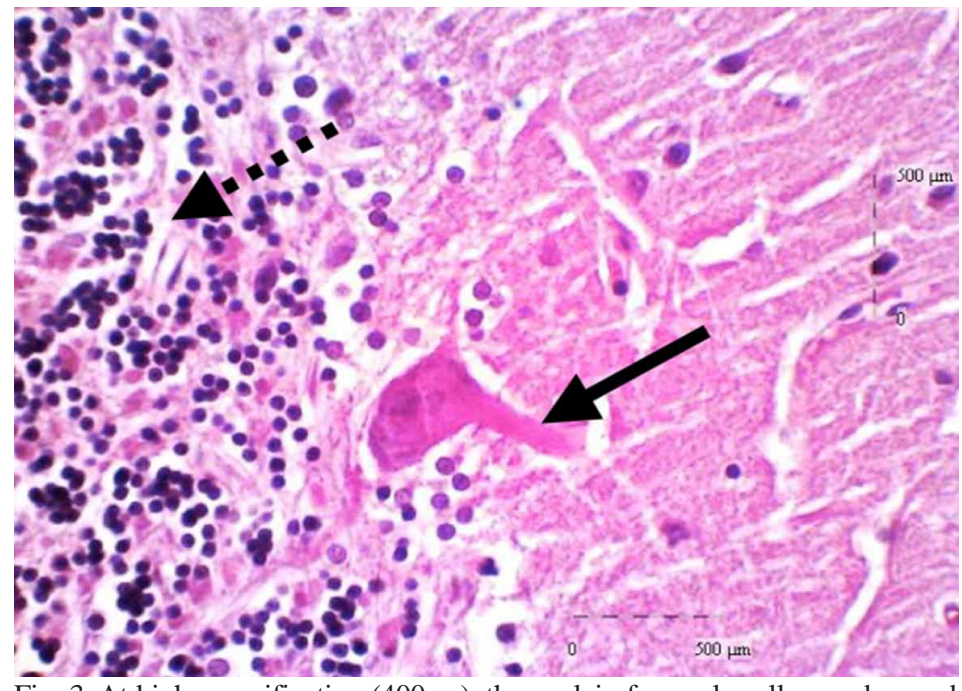

Fig. 3. At high magnification ( $400 \mathrm{xs})$, the nuclei of granule cells are observed well amongst the neuropils of the granular layer (broken arrow), whilst the dendrite of the Purkinje cell can be seen clearly along the molecular layer (arrow).

\section{RESULTS}

In this study, morphology of the cellular and cytoskeletons from each cerebellum can be observed clearly. In Figures 2a-b, the layers of cerebellar cortex are presented clearly; granular layer, Purkinje layer and molecular layer (40 xs and $100 \mathrm{xs}$ of magnifications). At high magnification (400 xs), the characteristic of the Purkinje cell can be seen with clear nucleus and dendritic processes spread along the molecular layer (Fig. 3). At the granular layer, the nucleus of each granular cell is seen amongst its neuropils (Fig. 3).

We found that there are 4 to 12 Purkinje cells observed from each field number (means $=12.05 \pm 2.9)$. There are no significant differences of the Purkinje cell numbers amongst cadaver's cerebelli $(\mathrm{p}=0.72)$. The distance between 2 Purkinje cells ranges between 82.6-346.6 $\mu \mathrm{m}$ (means $=179.3 \pm 18.4$ $\mu \mathrm{m})$ (Table I).

The total distance in a cerebellum is between 136.1-1696.62 $\mu \mathrm{m}$ (means $=865.7 \pm 84.7$ $\mu \mathrm{m})$. There are no significant differences either in the distance between 2 Purkinje cells $(\mathrm{p}=0.42)$, or in the total distance of all Purkinje cell's nuclei amongst these 3 cerebelli $(\mathrm{p}=0.1)$. The density of the Purkinje cells is approximately $0.01 \pm 0.004$ $\mu \mathrm{m}$, with no significant difference among these 3 cerebelli $(\mathrm{p}=0.34)$. The thickness of the molecular layer is between 309.4-779.62 $\mu \mathrm{m}$ (means $=$ $443.9 \pm 32.2 \mu \mathrm{m}$ ). There is a significant different of the thickness of the molecular layer amongst these 3 cerebelli, with $p=0.015$. All data can be observed in Table I. 


\section{DISCUSSION}

In this study we found that the number and the density of the Purkinje cells are not significantly different among individuals. The similarity of race and sex might cause these similar cerebellar characteristics. Although, nothing is known on the exact occupation when they alive, thus we are not able to correlate their movement skills with the current findings. Previous studies shown that there are approximately 15.4 millions of Purkinje cell nucleoli found in the human cerebellum (Nairn et al., 1989). This study was done in 12 adult human brains, regardless their sex. Other study showed that there are approximately 70 billion of neurons can be observed in the adult human cerebellum, with most of them reside at the granular layers (Barton \& Venditti, 2014). These cells formed the cerebellar folia, which are vast in numbers depend on the learned sequential movement in one's daily life. The vast number of one's cerebellar folia might be correlated to the number of sequential movement that has been learned by this individual (Glickstein et al., 2009; Watson et al., 2010; Takao et al., 2015).

On the other hand, there is a significant different in the thickness of the molecular layer found in the current study. Arguably, individual's difference in daily activities may play role. Molecular layer is the most outer layer of the cerebellar cortex. It is the location of the dendrites of the Purkinje cells, which make synapses to the other cells, including the basket and the stellate cells (Waxman; Fitzgerald et al.). These processes receive input from the mossy or climbing fibres from various area of the central nervous system, including pons, the brainstem and the spinal cord. These dendrites arrange themselves as a fan-like shape, forming a meticulous network within the cerebellar cortices folia. The input will pass to the deeper layer of piriform resided by the Purkinje cells (Glickstein et al.; Watson et al.; Fitzgerald et al.).

Although the physiology of the density of the Purkinje cells and the distance amongst them have yet determined, it is known that the Purkinje cells resided in between the outer molecular layer and the inner granular layer of cerebellar cortex plays vital function especially in the movement coordination (Bastian, 2006). The Purkinje dendrites are abundantly placed in the molecular layers where these will outreach till the surface of the cerebellar cortex. The dendritic arborisation is then paralleled along the length of the folia. These structures received excitatory input either from the spinal cord via the spinocerebellar tract, the inferior olive nucleus via the olivocerebellar tract, the vestibular nucleus via vestibulocerebellar tract and the pons via pontocerebellar tract. The conduction will be either via mossy fibres or the climbing fibres (Fitzgerald et al.; Crossman \& Neary).
The Purkinje cells also received contributions from the granule cells, which received the input from various sources including the spinal cord and the brain stem. The output of the Purkinje cells will be passed through their axons which will project deep into the cerebellar nuclei, which are located in the heart of cerebellar white matter (Fitzgerald $e t$ al.; Crossman \& Neary). The axon of the Purkinje cells is the only one that will leave the cerebellum to make connections through the dentate nuclei with other central nervous system such as the red nuclei of the mesencephalon, the ventral lateral nuclei of thalamus, especially the ventrolateral (VL) and the ventroposterolateral (VPL) nuclei, and the contralateral cerebral cortex and pons (Fitzgerald et al.; Crossman \& Neary).

The Purkinje cells themselves have g-amino butyric acid predominantly as their neurotransmitter. Thus, all in all, the conduction will occur through the inhibitory of the cerebellar nuclei. The inhibitory modulation in the intracortical circuit comes from other type of cells including Golgi (Neuron stellatum magnum), basket cells and stellate cells (Watson et al.; Waxman).

From previous studies, it was reported that cerebellar lesions/damage can manifest from asymptomatic to blantant pathology (Boyd, 2010; Gordon, 2007). It is reported that cerebellum damage may cause disruption of motor coordination and precision, qualities that are important in producing a smooth and sequential movement (Bastian). Furthermore, vision abnormality can also be found, arguably due to the cerebellum location that is not far from the primary visual cortices around the calcarine sulcus of occipital lobe (Ellis; Crossman \& Neary, 2015). Other studies reported that cerebellum lesions would likely correlated to the impairment of cognitive function and also dysarthria (Gordon; Glickstein et al.). The cognitive function could be impaired in this case perhaps because cerebellum also serves as a coordinator of impulse to and from the cerebral cortices. The cognitive functions impaired included mood, personality and emotion. On the other hand, dysarthria is likely produced due to the impairment of cerebellum as a muscle tone control centre via the globose and emboliform nuclei (Gordon; Glickstein et al.; Crossman \& Neary). Last but not least, the ability to maintain balance or equilibrium of one's body could be altered in pathology of cerebellum including stroke that attacked the posterior inferior cerebellar artery (PICA). This may be due to the connection between cerebellum deep nuclei of fastigial and the vestibular nuclei of the brainstem (Watson et al.; Fitzgerald et al.; Crossman \& Neary). Further study is called to determine the connectivity between cerebellum cellular and cytoskeleton's anatomy and physiology. 


\section{CONCLUSIONS}

There is a distinct morphology in one's cerebellum cellular population and morphology. These, arguably, because of the characteristic of one's daily life and learned movement, although there are some similarities found in the current study that might be due to the similarity of age and race.

\section{ACKNOWLEDGEMENTS}

Thank you to The Faculty of Medicine, Airlangga University for the funding and support given in this study.

KALANJATI, V. P.; DEWI, A. K. \& SANTOSO, M. W. A. Estudio cuantitativo de la corteza del cerebelo humano a partir de la anatomía de preparaciones cadavéricas. Int. J. Morphol., 35(1):167-171, 2017.

RESUMEN: El cerebelo humano es importante en la coordinación motora, los tonos musculares y el mantenimiento del equilibrio del cuerpo. En nuestra región, son limitados los datos disponibles en relación a la morfología normal del cerebelo humano, por otra parte obtener una biopsia fresca es bastante difícil de obtener. Para este trabajo se utilizaron tres cerebelos adultos de sexo masculino, obtenidos a partir de cadáveres conservados con una solución de formalina al $37 \%$ durante más de un año. Después de la separación, el hemisferio derecho del cerebelo fue seccionado en cubos que fueron posteriormente impregnados en una solución de $50-60 \%$ de alcohol antes del proceso de parafinización. Se tomaron dos secciones parasagitales adyacentes $(5 \mu \mathrm{m})$ de cada muestra desparafinada y luego éstas fueron teñidas con Hematoxilina-Eosina. Las muestras se observaron al microscopio óptico (Olympus, Japón). Se analizaron 6 campos por muestra con los softwares Optilab e Image Raster 3 (Indonesia). Se midieron la densidad de las neuronas purkinjenses (células de Purkinje), el número y densidad de ellas y el espesor de la capa molecular. Los datos fueron analizados con un nivel de significación de $\mathrm{p}<0,05$ (ANOVA, Microsoft Excel 2007). La distancia entre dos células de Purkinje varió entre 82,6-346,6 $\mu \mathrm{m}$, sin encontrarse diferencias significativas $(\mathrm{p}=0,1)$. No hay diferencias significativas en el número $(\mathrm{p}=0,72)$ y la densidad $(\mathrm{p}=0,34)$ de células de Purkinje entre las muestras; podría deberse a la misma edad, el sexo y la raza de los cadáveres utilizados. Sin embargo, hay una diferencia significativa en el espesor de la capa molecular $(p=0,015)$. Se observaron variaciones individuales en el cerebelo, encontrándose diferencia significativa el espesor de la capa molecular. La composición celular del cerebelo es única, sin duda esta se correlaciona con la actividad del cerebelo en individuos vivos.

PALABRAS CLAVE: Metencéfalo; Corteza cerebelosa; Medición; Estructura.

\section{REFERENCES}

Barton, R. A. \& Venditti, C. Rapid evolution of the cerebellum in humans and other great apes. Curr. Biol., 24(20):2440-4, 2014.

Bastian, A. J. Learning to predict the future: the cerebellum adapts feedforward movement control. Curr. Opin. Neurobiol., 16(6):645-9, 2006.
Boyd, C. A. Cerebellar agenesis revisited. Brain, 133(Pt. 3):941-4, 2010. Chatterjee, S. Artefacts in histopathology. J. Oral Maxillofac. Pathol., 18(4):111-6, 2014

Crossman, A. R. \& Neary, D. (Eds.) Neuroanatomy. An Illustrated Colour Text. $5^{\text {th }}$ ed. Edinburgh, Churchill Livingstone / Elsevier, 2015. pp.111-8.

Ellis, H. Clinical Anatomy: Applied Anatomy for Students and Junior Doctors. $11^{\text {th }}$ ed. Chichester, John Wiley \& Sons, 2006.

Fitzgerald, M. J. T.; Gruener, G. \& Mtui, E. Clinical Neuroanatomy and Neuroscience. $6^{\text {th }}$ ed. Edinburgh, Saunders/Elsevier, 2012. pp.267-76.

Glickstein. M.; Strata, P. \& Voogd, J. Cerebellum: history. Neuroscience, 162(3):549-59, 2009.

Gordon, N. The cerebellum and cognition. Eur. J. Paediatr. Neurol., 11(4):232-4, 2007.

Takao, H.; Hayashi, N. \& Ohtomo, K. Brain morphology is individualspecific information. Magn. Reson. Imaging, 33(6):816-21, 2015.

IHC World. Paraffin Section Method and Technique. Website. IHC World Life Science Products \& Services, 2011a. Available from: http:// www.ihcworld.com/_protocols/histology/paraffin_section.htm

IHC World. Hematoxylin and Eosin $(H \& E)$ Staining Protocol. IHC World Life Science Products \& Services, 2011b. Available from: http:// www.ihcworld.com/_protocols/special_stains/h\&e_ellis.htm

Kalanjati, V. P.; Prasetiowati, L. \& Alimsardjono, H. The use of lower containing embalming solution for anatomy cadaver preparation. Med. J. Indones., 21(4):203-7, 2012.

Nairn, J. G.; Bedi, K. S.; Mayhew, T. M. \& Campbel, L. F. On the number of Purkinje cells in the human cerebellum: unbiased estimates obtained by using the "fractionator". J. Comp. Neurol., 290(4):527-32, 1989.

Watson, C.; Kirkcaldie, M. \& Paxinos, G. The Brain. An Introduction to Functional Neuroanatomy. Amsterdam, Academic Press, 2010. pp.5564.

Waxman, S. G. Clinical Neuroanatomy. $26^{\text {th }}$ ed. New York, McGraw-Hill, 2010. pp.91-8.

Corresponding author:

Viskasari P. Kalanjati, dr., M. Kes., PA(K), Ph.D.

Department of Anatomy and Histology

Faculty of Medicine, Universitas Airlangga

Surabaya, Indonesia 60131

Jl. Mayjen Prof. Dr. Moestopo No. 47

Surabaya, East Java, Indonesia 60131

INDONESIA

Phone: +62-31-5053804

Mobile phone: +62-81938271247

Email: viskasaripk@yahoo.com

Received: 21-07-2016

Accepted: 23-11-2016 